\title{
Application For Lecturer Recruitment Using Simple Additive Weighting (SAW) Method Case Study: TanriAbeng University Jakarta
}

\author{
Pramitha Dwi Larasati ${ }^{1}$, Ari Irawan ${ }^{2}$
}

\begin{abstract}
In the selection of acceptance of lecturers at a university can be done when the selected applicants have good competence by following with they are background because this can affect the teaching service. Lecturers who have good competence has the ability for understanding the subject matter that in line with the background, extensive knowledge, be able to speak English both oral and written and be able to provide a positive example and teaching methods that are easily understood by students. That can provide the right image for the university because the selected lecturers have good potential. To help determine the acceptance of lecturers then we needed a decision support system. Onemethodthatused for Decision Support System is using Simple Additive Weighting (SAW). The resultsofthisstudywere it canselect the best alternative from some alternatives, in thiscase, to determine the acceptanceoflecturers.
\end{abstract}

Keywords - Lecturer Recruitment, Simple Additive Weighting, SAW, fuzzy MADM, Criteria, Decision Support System

\section{INTRODUCTION}

A university is a unit of higher education. College learners are called students and educators are called lecturers. Higher Education should provide sufficient teaching staff to serve and provide quality teaching to its students. Regarding service quality in teaching, lecturers must have reasonable competence in their field. However, because of the need for these resources, universities become less selective in the admissions process.

The use of the Simple Additive Weighting (SAW) method has been used to determine the acceptance of a college scholarship [5], which is used to determine the best graduates of some required criteria ie GPA, study duration, final settlement (TA), Final Project (TA) [4], and is used to determine who is eligible to be accepted as an employee

Received: 25 September 2018; Revised: 19 febuari 2020; Accepted:10 Juli 2020

http://journal.uinjkt.ac.id/index.php/aism through a website. The criteria specified in this research are Grade Point Average (GPA), Age and Work Experience. These criteria will then be processed and produce a job applicant's decision to be called for further admission process [1]. Based on these things theauthorwillusethe SAW method in determining acceptance of lecturer at Tanri Abeng Unversity.

Fuzzy Multi-Attribute Decision Making (FMADM) method is a method that can find the best alternative from various alternatives based on predetermined criteria [8]. The point is that the method determines the weight value for each criterion. The method uses Simple Additive Weighting (SAW) to perform FMADM method calculations. The best alternative in question is the right to be accepted as a lecturer with the criteria that have determined. The purpose of this research is to apply Simple Additive Weighting (SAW) method in supporting a decision to determine the acceptance of lecturer.

Increasingly theuse of theinternet, thentheeasieraccessto the internet. Everyone can access the internet whenever and wherever. Based on that develop a webbasedsystemconsideredveryprofitable. Web-based information displays many benefits of multimedia technology. Using a fast broadband connection, it is possible to stream mature content to a computer anywhere in the world.Web-based system development is done using $\mathrm{Html}$ and PHP language [2].

Tanri abeng university is a growing university. In the development of one of them is the acceptance of lecturers as teaching staff. Recognition is done by looking at the Curriculum Vitae (CV) and doing interviews and micro teaching only. Lecturer acceptance is considered less selective and only because of the university's accreditation needsWith the increased of social interest for the university, they must provide enough teaching staff but also to serve and provide quality teaching to the students. Regarding quality of service in teaching, the faculty (lecturers) must have reasonable competence in the field. However, because of these needs, the college becomes less selective in the process of acceptance. The

${ }^{1}$ P.D. Larasati, Information System Department, Tanri Abeng University Jakarta, Indonesia (e-mail: pramitha.dwi@tau.ac.id)

${ }^{2}$ A.Irawan, Information System Department, Tanri Abeng University Jakarta, Indonesia (e-mail: ari_irawan@tau.ac.id) 
processes that lasted only consisted of one stage only the interview or question and answer between the party of personnel with lecturer applicants. Without any further process, the lecturer applicants have been accepted immediately and start teaching in the class for the next semester.

Based on the problems, the author develops a web-based system using Simple Additive Weighting (SAW) method as a data analysismethod and Waterfallmodel as a systemdevelopmentmodel.

\section{LITERATURE REVIEW}

The Simple Additive Weighting (SAW) method is often also known as the weighted summing method. The basic concept of the SAW method is to find the weighted sum of performance ratings on each alternative on all attributes. The SAW method requires the process of normalizing the decision matrix $(\mathrm{X})$ to a scale comparable to all current alternative ratings [4].

$$
r_{i j}= \begin{cases}\frac{x_{i j}}{\operatorname{Max}_{i} x_{i j}} & j i k a \mathrm{j} \text { adalah atribut keuntungan (benefit) } \\ \frac{\operatorname{Min}_{i} x_{i j}}{x_{i j}} & \text { jika jadalah atribut biaya (cost) }\end{cases}
$$

$\mathrm{r}_{\mathrm{ij}}$ isthe performance where normalized from $\mathrm{ij}$ alternative $\mathrm{A}_{\mathrm{i}} \mathrm{in}$ attribute $C_{j} ; i=1,2, \ldots, m$ and $j=1,2, \ldots, n$. The preference value for each alternative (Vi) given as [8]:

$$
V_{i}=\sum_{j=1}^{n} w_{j} r_{i j}
$$

A larger $V_{i}$ value indicates that Ai's alternatives are preferred.

\section{METHODS}

\section{A. Framework}

From the problems studied, the following framework is structured by:

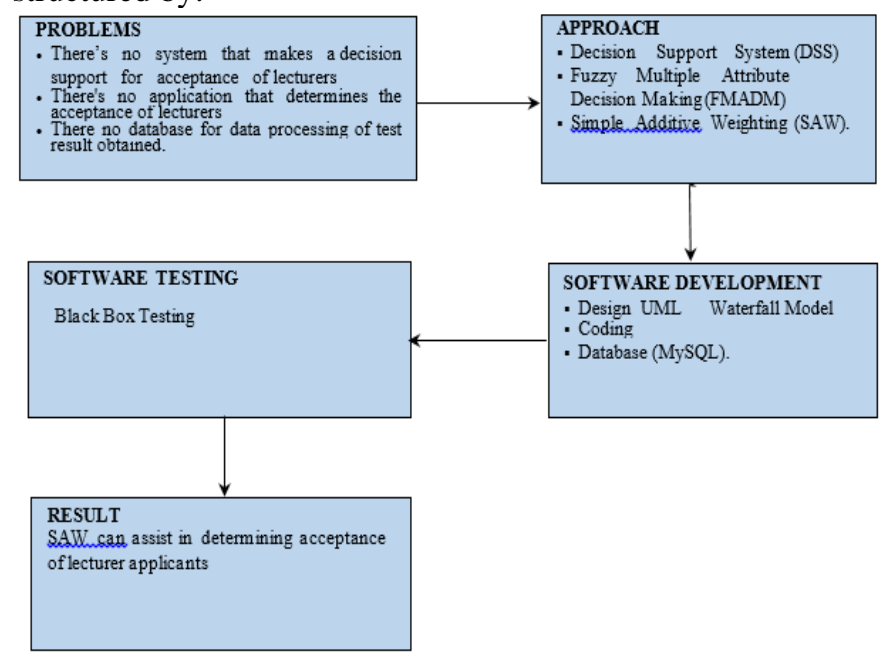

Fig 1. Framework

\section{B. Methodology}

This study contains seven stages that shown in figure 2,(1) At this stage the problem will be identified. Input from this activity is to determine the topic of the problem to be studied based on a literature study. Next (2) Determine the scope of the organization and Identify the organization needs on the existing data flow process, existing input and output data, the actors involved. (3)Process the data that have been collected based on this research. Next (4) design a system s using use case, class diagram, and interface design. (5) make a database design with determine a primary key, foreign key and data type based on previous steps using MySQL. (6) code a system with HTML and PHP language, and this system will build as a web-based system. (7) Also, testing a system with black box testing and white box testing.

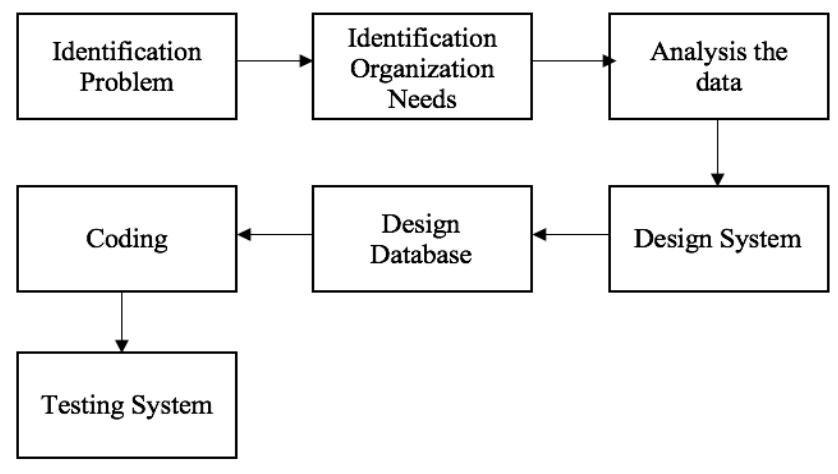

Fig 2. Research Methodology

\section{RESUlT}

Based on problems that have been described before, the authors do this research, the selection process of lecturer acceptance consists of only one stage is the interview process, so that the decision taken is not fundamental. Decreasing the quality of teaching services can occur due to the lack of proficient lecturers in the mastery of the material and how to explain the material in question to the students. This research is experimental research, and in its implementation requires several instruments, namely: the data taken is the result of some lecturer acceptance selection process then formed a table so that it meets the required attributes. Attributes of data needed in this research are:

Table 1.

Data Needs

\begin{tabular}{ccccc}
\hline \hline & \multicolumn{3}{c}{ Alternative } \\
Criteria & $\begin{array}{c}\text { TesPengetahuanUmu } \\
\text { m } \\
\text { (General Knowledge } \\
\text { Test) }\end{array}$ & $\begin{array}{c}\text { Tes } \\
\text { Bahasa } \\
\text { Inggris } \\
\text { (Englis } \\
\text { h Test) }\end{array}$ & $\begin{array}{c}\text { Tes } \\
\text { Psikologi } \\
\text { (Psychologic } \\
\text { al Test) }\end{array}$ & $\begin{array}{c}\text { Tes } \\
\text { Mengaja }\end{array}$ \\
$\begin{array}{c}\text { Pelama } \\
\text { r 1 } \\
\begin{array}{c}\text { Pelama } \\
\text { r 2 }\end{array}\end{array}$ & 60 & 65 & 70 & 70 \\
$\begin{array}{c}\text { Pelama } \\
\text { r 3 }\end{array}$ & 70 & 75 & 80 & 85 \\
\hline \hline
\end{tabular}

http://journal.uinjkt.ac.id/index.php/aism 


\begin{tabular}{ccccc}
\hline \hline $\begin{array}{c}\text { Pelama } \\
\text { r 4 } \\
\text { Pelama } \\
\text { r 5 }\end{array}$ & 75 & 65 & 80 & 80 \\
\hline \hline
\end{tabular}

The data in table 1 takes from the personnel file. In this research method, there are Criteria and Alternatives needed to determine who will accept as a lecturer at TanriAbeng University. The criteria areas follows:

C01 $=$ TesPengetahuanUmum (General Knowledge Test)

$\mathrm{C} 02=$ Tes Bahasa Inggris (English Test)

C03 $=$ TesPsikologi (Psychological Test)

C04 $=$ TesMengajar $($ Teaching Test $)$

The weights determined by the decision makers of the established criteria are as follows: $\mathrm{C} 01=25 \%, \mathrm{C} 02=30 \%, \mathrm{C} 03=$ $20 \%$, C04 $=25 \%$.From each weight, then made a variablevariable. Where from a variable will be converted into fuzzynumber. Figure 3 show the fuzzy number of all test, and below is the number of attributes:

1. Fuzzy Number for General Knowledge Test attribute
a. $\operatorname{Gagal}(\mathrm{G})=0-0.24$
b. CukupMemuaskan $(\mathrm{CM})=0.25-0.4$
c. $\operatorname{Memuaskan}(\mathrm{M})=0.5-0.74$
d. SangatMemuaskan ( SM $)=0.75-0.89$
e. Istimewa ( I ) $=0.9-1$

2. Fuzzy Number for English Test attribute
a. $\operatorname{Gagal}(\mathrm{G})=0-0.24$
b. CukupMemuaskan $(\mathrm{CM})=0.25-0.4$
c. Memuaskan $(\mathrm{M})=0.5-0.74$
d. SangatMemuaskan ( SM ) $=0.75-0.89$
e. Istimewa ( I ) $=0.9-1$

3. Fuzzy Number for Psychological Test attribute
a. $\operatorname{Gagal}(\mathrm{G})=0-0.24$
b. CukupMemuaskan( $\mathrm{CM})=0.25-0.4$
c. Memuaskan $(\mathrm{M})=0.5-0.74$
d. SangatMemuaskan $(\mathrm{SM})=0.75-0.89$
e. Istimewa ( I ) $=0.9-1$

4. Fuzzy Number for Teaching Test attribute
a. $\operatorname{Gagal}(\mathrm{G})=0-0.24$
b. CukupMemuaskan( $\mathrm{CM})=0.25-0.4$
c. Memuaskan $(\mathrm{M})=0.5-0.74$
d. SangatMemuaskan $(\mathrm{SM})=0.75-0.89$
e. Istimewa ( I ) $=0.9-1$

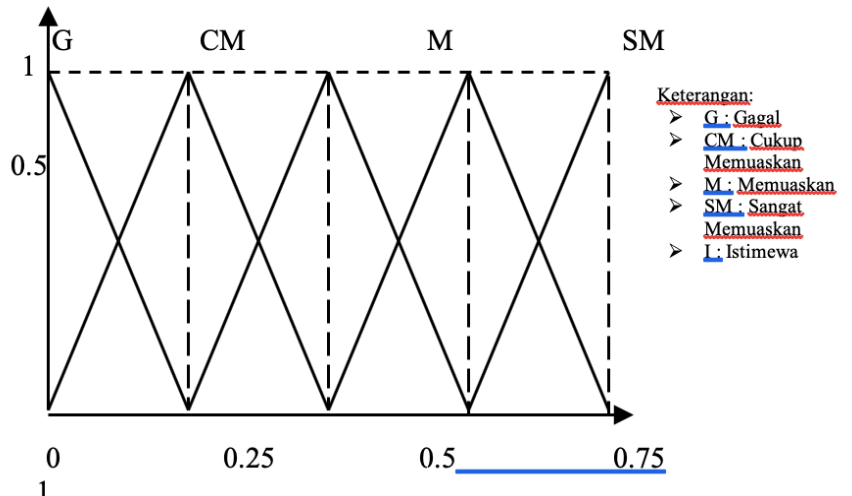

Fig 3. Fuzzy Number for All the Test

So regarding the information, Table 1 can be formed the decision matrix $\mathrm{X}$ that shown in figure 4 .

$X=\left[\begin{array}{cccc}\text { Satisfy } & \text { Satisfy } & \text { Very Satisfy } & \text { Very Satisfy } \\ \text { Satisfy } & \text { VerySatisfy } & \text { Very Satisfy } & \text { Special } \\ \text { Satisfy } & \text { VerySatisfy } & \text { Satisfy } & \text { VerySatisfy } \\ \text { Satisfy } & \text { Satisfy } & \text { Very Satisfy } & \text { VerySatisfy } \\ \text { Special } & \text { VerySatisfy } & \text { Very Satisfy } & \text { VerySatisfy }\end{array}\right]$

Figure 4. Decision Matrix

\section{A. Decision Matrix}

In this research using Fuzzy Multi-Attribute Decision Making (FMADM) with Simple Additive Weighting Method (SAW) method. The steps are:

- Determine the criteria that will be used as a reference in decision making that is $\mathrm{C}_{\mathrm{i}}$

- Specifies each alternative's match rating on each criterion.

- Create a decision matrix based on a criterion $(\mathrm{Ci})$, then do the normalization of matrix based on an equation which is adjusted to attribute type (attribute advantage or cost attribute) so obtained normalized matrix R. [4]

\section{B. DSS Design}

The final result obtained from the ranking process that is the sum of the normalized matrix multiplication $\mathrm{R}$ with a weight vector to obtain the most significant value chosen as the best alternative (Vi) as a solution. The steps that will pass in this research are as follows:

\section{1) Determination of Research Problems}

The problem in this study is how to determine the acceptance of lecturers by not only based on one attribute because if only based on one attribute the possibility to occur the same value is very likely to occur frequently. This study using several attributes (criteria) namely General Knowledge Test (C01), English Test (C02), Psychological Test (C03), Teaching Tests (C04). Moreover, in the literature, it is found that fuzzy MADM can assist decision makers by selecting alternatives with attributes (criteria) 
with the best features and classifying alternatives based on specific roles [4]. The hierarchy of problems can be seen in figure 5.

2) Determination of Computing Approach

Computing Approach used in this research is Fuzzy MultiAttribute Decision Making (FMADM) with Simple Additive Weighting Method (SAW).

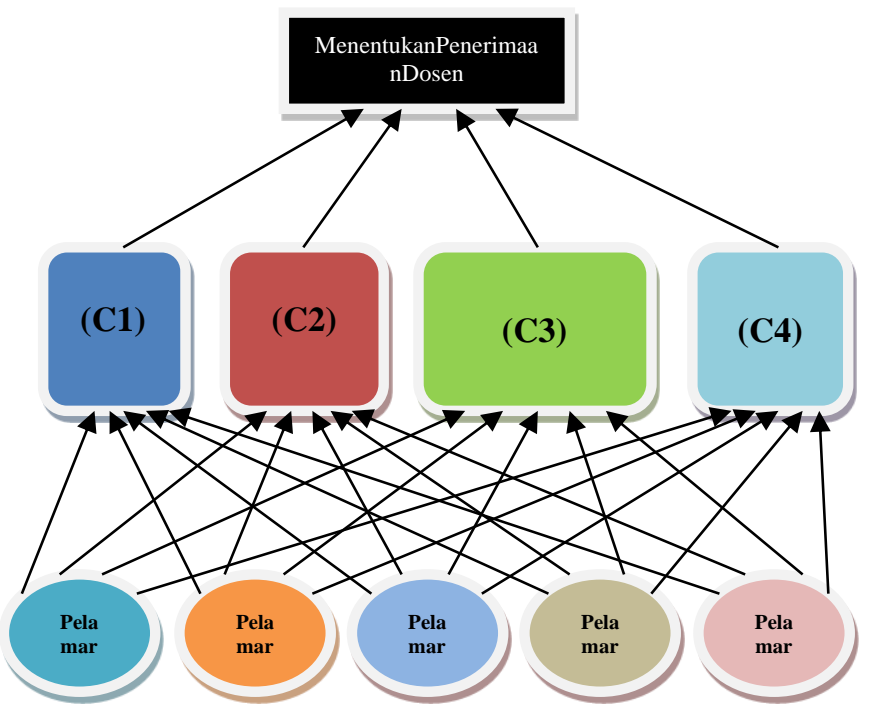

Fig 5. Hierarchy of Problems

3) Software Development

The method used in software development in this research is The Waterfall method. This method divides the process of software development into individual phases or steps. Phase or step with each other is chronologically and functionally separated.Thewaterfall modelis of the models contained in the application of System [10], divided waterfall model into steps, that is System and software design, Requirements definition, Implementation, and unit testing, Integration and system testing, and Operation and maintenance, it is shown in Figure 6.

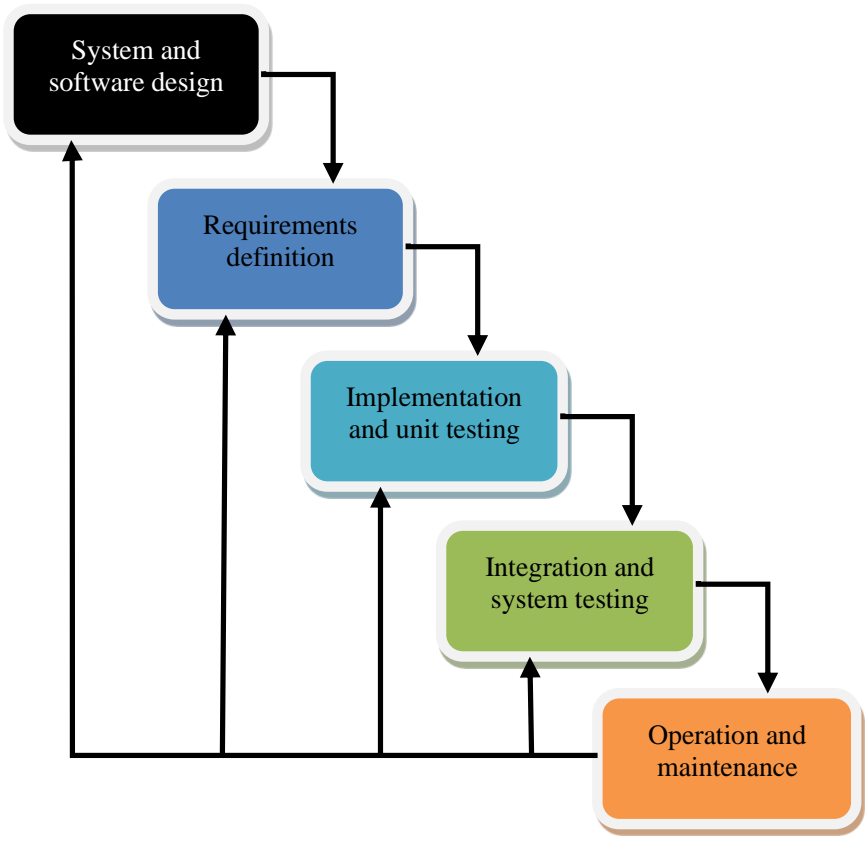

Fig 6. Waterfall Model Scheme

The waterfall model used for the development of this application but not all stages done while the stages in the waterfall process model used to complete this research are Requirement Analysis, System Design, and Database Design.

\section{System Design}

The design of the system used in the design of this system using UML (Unified Modeling Language) is a tool for analysis and design of object-based software [1], a thirdgenerationmodelingmethod and a non-proprietary specification language. Actually, the usage of UML itself is not limited only to the world of modeling software, but it can also be used for hardware modeling (engineering systems) and often used as modeling for business processes as well as modeling for organizationalstructure. To make it easier to understand in this case the following illustrated in the form of diagrams.

\section{1) Use Case Diagram}

To explain the picture of the system and the actors involved as a whole need to made the Use Case Diagram. The use case diagram component consists of Actor, use case and relation. The actor is a player, while the use case is what he/she does with the relation as the pointer. Notation drawing used Use Case Diagram RekrutmenDosen shown in figure7. 


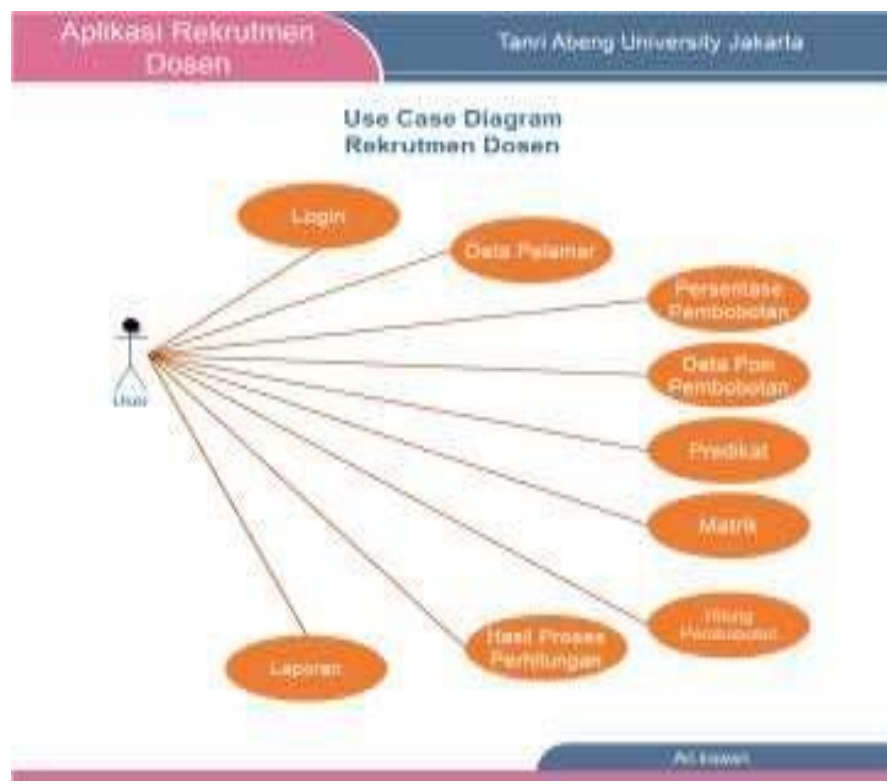

Fig 7. Use Case Diagram RekrutmenDosen

2) Class Diagram

Afterwemakea Use Case Diagram, the next step is to create a Class Diagram based on the Use Case Diagram. This class diagram contains objects.Class Diagramisshown in figure 8 .

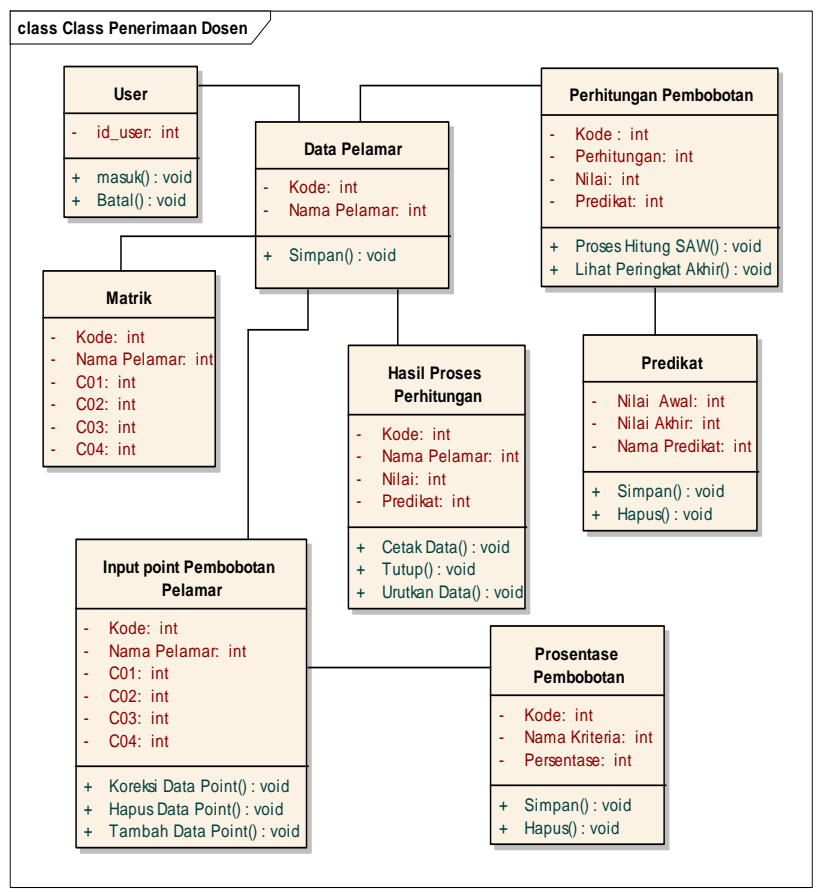

Fig 8. Class Diagram PenerimaanDosen

\section{Database Design}

This section describes the physical design of the necessary tables and relationships between tables for system design all collected in a single database (see in figure 9). By following the SAW method of production SAW method can produce output per under the calculation method of the SAW. In the view of this form, there are four main parts of the Applicant Data field, Data criteria, Data Point, Data Range Weight. The command buttons contained in this form are the Save button, Delete, Add Data Point, Edit Data Point, Delete Data Point. Figure 10 shown Master Data form.

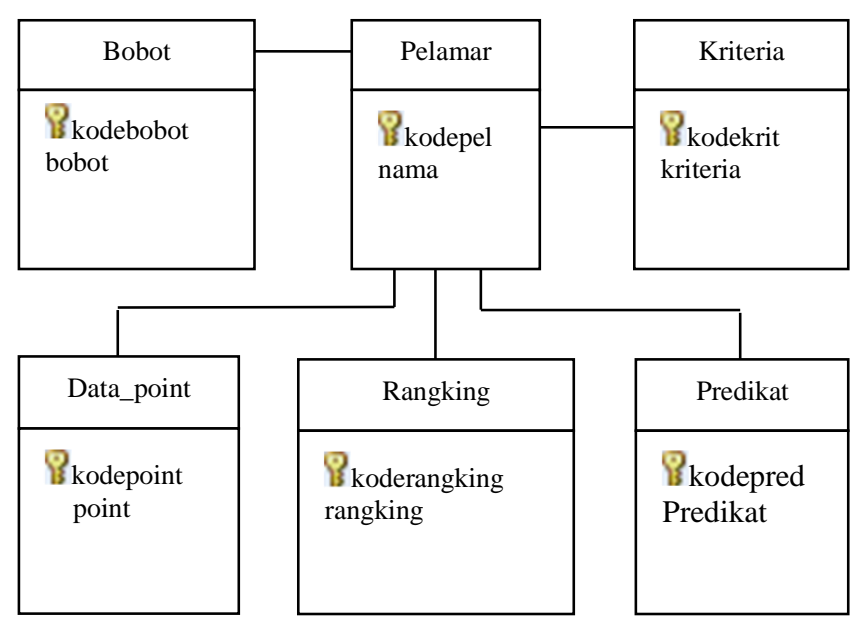

Fig 9. EntityRelationshipDiagramRekrutmenDosen

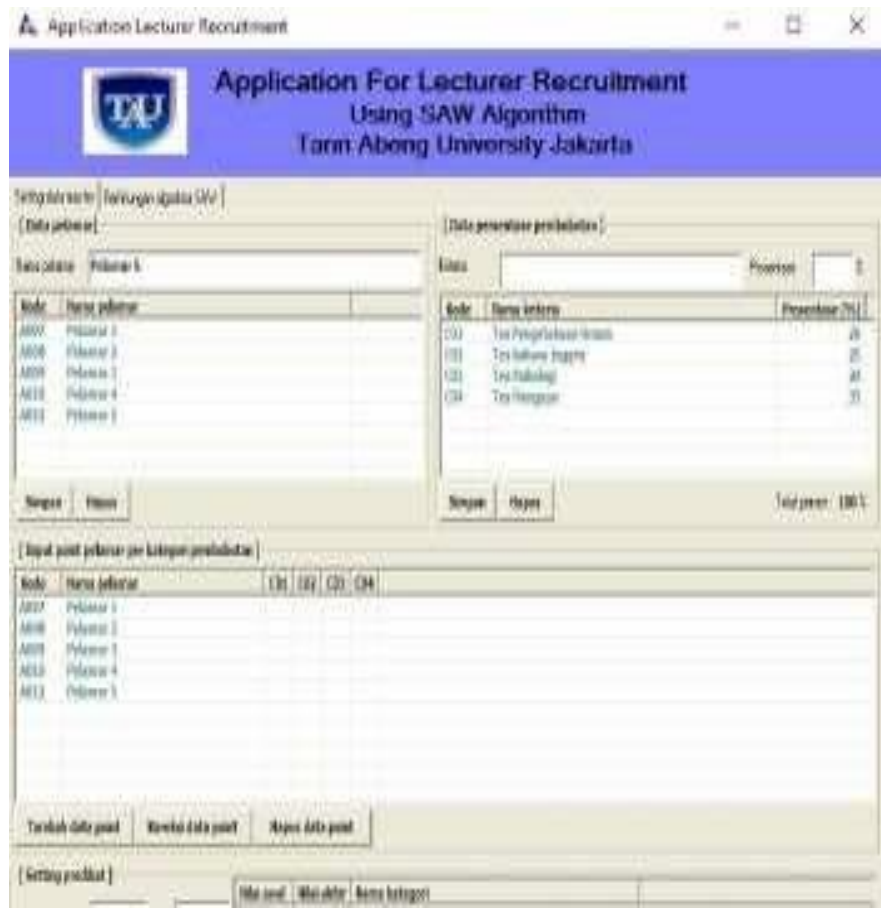

Fig 10. Data Master Form

Then the user can continue to the 2nd form of the SAW algorithm computation form. In this form, two buttons include the SAW Calculate Process button and View the Last Rank. Users will display the overall calculation data so that directly obtained the highest value calculation then the data will be 
calculated to generate the predicate of each test score. By pressing the SAW Calculate Process button then the calculation of test result data will be done. Figure 11 show pictures of the SAW algorithm computation form.

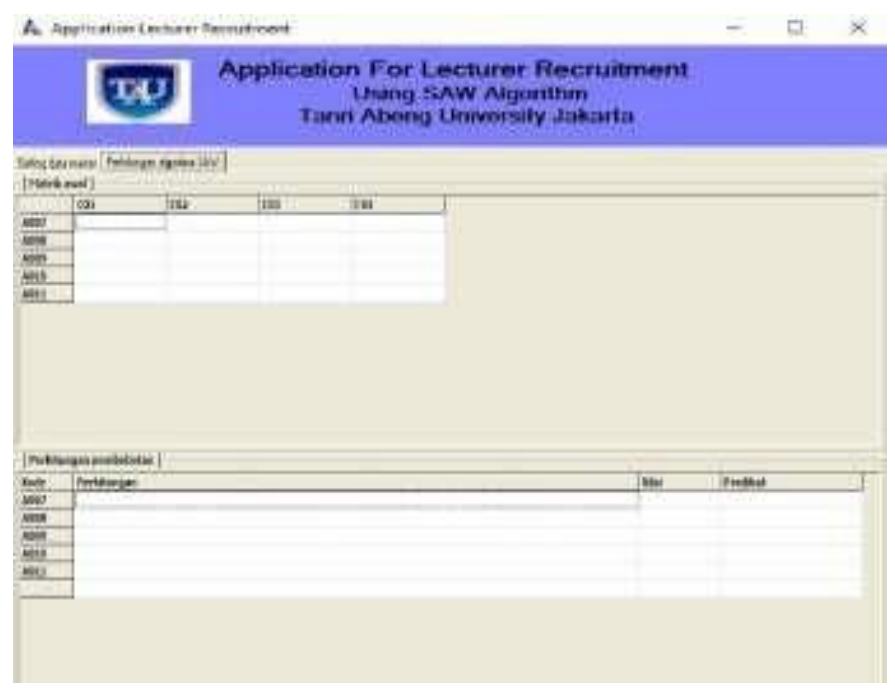

Fig 11. SAW Algorithm

After the results obtained calculations can then be forwarded by making a form of printed reports using paper and printers as a means of printing. By pressing the button to rate the final value rating, it will exit the display as follows (See Figure 12).

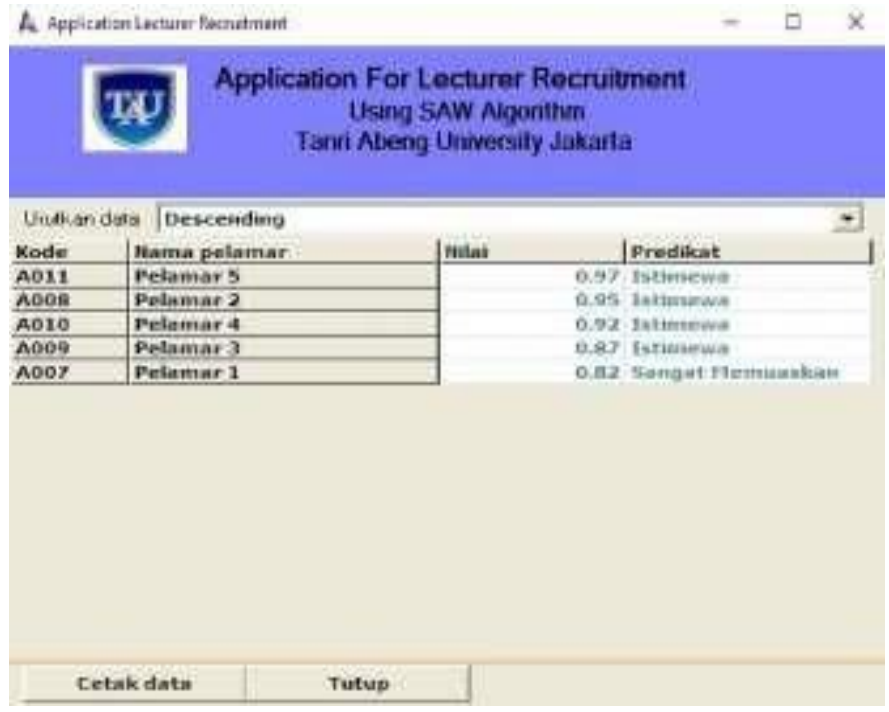

Fig 12. The Result of Data Calculating

After the above view is then the next command is pressing the Print Data button. Then this application will make a connection with the Microsoft Excel program as an intermediate for the calculation result can print in table form. The display results calculations contained in Microsoft Excel is as follows (seen Figure 13).

\begin{tabular}{|c|c|c|c|c|c|}
\hline & $A$ & E & $c$ & 0 & \\
\hline \multicolumn{6}{|c|}{ Hasil Penilaian Penerimaan Dosen Baru } \\
\hline 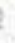 & Tariggal Cetak & 31-March-2018 16:08 & & & \\
\hline 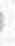 & Jumlah Pelamar & 5 & & & \\
\hline 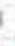 & Unut Dats & Descending & & & \\
\hline & Kode & Nama Pelamar & Nilai & Predikat & \\
\hline & A011 & Pelamar 5 & 0.97 & btimews & \\
\hline t & $A 00 B$ & Pelamac 2 & 0.95 & istimewa & \\
\hline 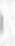 & A010 & Pelamat 4 & 0.92 & Hainewa. & \\
\hline & $A C O 9$ & Pelomar 3 & 0.87 & Istimewa & \\
\hline & $A 007$ & Pelamar 1 & 0.82 & Sangat Memuaskan & \\
\hline & & & & & \\
\hline 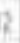 & & & & & \\
\hline
\end{tabular}

Fig 13. Microsoft Excel Output

\section{CONCLUSION}

Simple Additive Weighting (SAW) method is one part of the method contained in th Fuzzy Multi-Attribute Decision Making (FMADM). This method is very appropriate to be used for decision support because this method uses an attribute and a weighting value that can eventually produce a predicate. The value of this weighting calculation use for decision support.

The stages applied in the application made so that the calculation will be faster and can simplify the decision-making process. With the application of a decision support system using Simple Additive Weighting (SAW) method, the decisionmaking process becomes more necessary and can do quickly. This application can be immediately used to process the calculation of test results that have been undertaken by the applicants.

\section{REFERENCES}

[1]. Arista, Yuni. 2011. "Rancang Bangun Aplikasi Pengelolaan Lowongan Kerja Di Palembang Berbasis Web Menggunakan Fuzzy Logic". Palembang: STMIK MDP

[2]. Indrajat, Eko Richardus, Prastowo, Bambang N, danSyukri, Muhammad. 2000. BukuPintar Linux. Aplikasi Web Database Menggunakan PHP \& MySQL. P.T. Elex Media Komputindo, Jakarta.

[3]. Kusumadewi, S., \& Purnomo, H. 2004. "Aplikasi Logika Fuzzy untuk Pendukung Keputusan”. Yogyakarta: Graha Ilmu.

[4]. Kusumadewi, Sri., Hartati, S., Harjoko, A., danWardoyo, R. 2006. "Fuzzy Multi-Attribute Decision Making (FUZZY MADM)". Yogyakarta: PenerbitGrahaIlmu.

[5]. Mukiman, Kiki. 2011. "Penerapan Fuzzy Multi Attribute Decision Making (MADM) Dalam Mendukung Keputusan Untuk Menentukan Lulusan Terbaik"

[6]. Pahlevy, Randy Tesar. 2011. "Rancang Bangun Sistem Pendukung Keputusan Menentukan Penerima Beasiswa Dengan Menggunakan Metode Simple Additive Weighting (SAW)". Surabaya :Universitas Pembangunan Nasional "Veteran" JawaTimur.

[7]. Roger S. Pressman, P. 2001." Software Engineering A Practitioner's Approach". New York.

[8]. Sri Kusumadewi, Sri Hartati, Agus Harjoko, Retantyo Wardoyo. 2006. Fuzzy Multiple Attribute Decision Making (FUZZY MADM). Yogyakarta: GRAHA ILMU.

[9]. Sugiri, H.S. 2008. Pengelolaan database MySql dengan PhpMyAdmin. Yogyakarta: GrahaIlmu.

[10]. Welling, Luke dan Thomson, Laura. PHP \& MySQL Web Development. Sams Publishing, USA. 2001. 